\title{
SUBSTAKITIATIOH OF THE SELL-by DATE OF FOOD PRODUCTS
}

\author{
S. Kuzminsky, T. Adamchuk, O. Holinko, N. Levicka \\ L.I. Medved's Research Center of Preventive Toxicology, Food and Chemical Safety, Ministry of Health, \\ Ukraine (State Enterprise), Kyiv, Ukraine
}

\begin{abstract}
Objective of the Work. The overview of current methodical approaches for experimental substantiation of the sell-by date of food products.

Methods and Materials. Data analysis of scientific literature and normative documents on methods of substantiation of the sell-by date of food products.

Results and Discussion. Sell-by date is a period since product's manufacture, during which it maintains its safety and quality (including nutritional value) within reasonably foreseeable conditions of storage, distribution and consumption. In the case of new products (recipes) introduction it is necessary to review the sell-by date, and its extending as the need arises. The main aspects of microbiological substantiation of the sell-by date of food products are considered. The identification of microbial hazard for particular product is the first phase of the work. The second phase of the work is to determine the kinetic parameters of precise microorganism's accumulation to maximum permitted level within regulated and aggravated conditions of product's storage.

Conclusions. In the process of microbiological substantiation of the sell-by date of food products it should be taken into consideration the presence of leading pathogen and causative microorganisms of microbial spoilage, the initial contamination level, the lag phase duration of germ culture development, variations between strains, the kinetics of microorganisms' accumulation within the product in real and aggravated storage conditions, the indetermination connected with biological nature of microorganisms and their inhomogeneous allocation within the product, the limitation for shortcut research methods (if applicable). The decision rule should be based on the consumer's risk concept.
\end{abstract}

Key Words: food products, sell-by date, substantiation, microbiological indicators.

Objectives. The overview of current methodical approaches for experimental substantiation of the sell-by date of food products.

Methods of experimental substantiation of the sell-by date of food products in Ukraine should be unified and approved as required, with relation to large request for such researches and deficiency of adequate normative documents. However, there is a large amount of international and national prescriptive about this question [1, $2,3,4,5]$.

According to these prescriptive, the sell-by date is a period since food product's manufacture, during which it maintains its safety and quality (including nutritional value) within reasonably foreseeable conditions of storage, distribution and consumption. As usual, sell-by date is noted on the label as "use by ..." - for products with high risk of microbial affection or it is noted as "best before ..." - for other products, which includes products with sell-by date over 18 months.

In the case of new products (recipes) introduction it is necessary to substantiate the sell-by date, and its extending as the need arises.
There are mechanisms of time changes of food products quality and safety which can be: microbiological, chemical, physical, including those associated with temperature effect.

Possibility of peculiar microorganisms' accumulation in the process of food products storage first of all depends on the initial microbial contamination level, the lag phase duration of germ culture development, variations between strains, physical and chemical features of the product (including humidity and reaction of environment $(\mathrm{pH})$, food additives presence, processing technique during cooking, storage conditions of the product (temperature, gaseous medium). The information related to influence of external factors on the ability of some pathogenic microorganisms and causative microorganisms of microbial spoilage of food products is given in Table 1. It should be noted that mentioned borders of influence pertain to each separate external factor, but their combined effect can be significantly different [3]. For instance, the beginning of exponential phase of L.monocytogenes' reproduction in case of $\mathrm{pH} 5$ is being observed in 10 days, but in case of water activity Aw 0,94 - in 
12 days. But, in case of their synchronizing action this indicator was being risen to 16 days.

The accumulation of food-borne pathogen, including Salmonella, L.monocytogenes, E.coli of 0157:H7 serotype, can be in process without change in product's organoleptic features and create a health hazard to consumers at the same time. However, the reproduction of causative microorganisms of microbial spoilage leads to the loss of product's marketable condition, sometimes without influence on product's safety.

Methodical approaches to microbiological substantiation of the sell-by date of food products include:

- the observation of product's microbiological condition during the period of registered sellby date (including reserved period) in real storage conditions, in particular with the consideration of possible deviation from recommended conditions,

- the dynamics determination of the number of targeted microorganisms in the product after its artificial inoculation within real storage conditions ("challenge test"),
- shortcut methods (with the use of aggravated conditions and mathematical modeling of possible increase of the number of microorganisms within the product ("prognostic microbiology").

But in any case, the identification of microbial hazard for particular product is the first phase of the work. It is known that Listeria monocytogenes is a risk factor for cooled goods ready-to-feed, and the risk factor for ready-to-eat products from seafood in vacuum packing is non-proteolytic serotypes Clostridium botulinum. The ascertainment of kinetic parameters of precise microorganism accumulation to maximum permitted level (national safety standard) within regulated and aggravated conditions of product's storage will be the second phase.

It is important to determine required study duration. It is not enough to be based just on expected sell-by date of product, because a lot of uncertain factors influence on the duration of the expiry date of product for consumption. It would be unrealistic to expect its stability and reproducibility in all circumstances. It is most

Table 1

Minimal conditions for the reproduction of some pathogenic microorganisms and causative microorganisms of microbial spoilage of food products by Latuful Bari, 2009 [6]

\begin{tabular}{|c|c|c|c|c|}
\hline Type of microorganisms & $\begin{array}{c}\text { Reaction of } \\
\text { environment } \\
(\mathrm{pH})\end{array}$ & $\begin{array}{l}\text { Water activity } \\
\left(a_{w}\right)\end{array}$ & $\begin{array}{l}\text { Growth under } \\
\text { anaerobic } \\
\text { conditions }\end{array}$ & $\begin{array}{c}\text { Temperature } \\
\left({ }^{\circ} \mathrm{C}\right)\end{array}$ \\
\hline \multicolumn{5}{|c|}{ Pathogenic microorganisms } \\
\hline Salmonella & 4,0 & 0,94 & Yes & 7 \\
\hline Listeria monocytogenes & 4,3 & 0,92 & Yes & 0 \\
\hline $\begin{array}{l}\text { Clostridium botulinum } \\
\text { proteolytic A, B, F } \\
\text { non-proteolytic B, E, F }\end{array}$ & $\begin{array}{l}4.6 \\
5,0\end{array}$ & $\begin{array}{l}0,93 \\
0,97\end{array}$ & Yes & $\begin{array}{c}10 \\
3\end{array}$ \\
\hline $\begin{array}{l}\text { Toxin production } \\
\text { Staphylococcus aureus }\end{array}$ & 4,0 & 0,83 & Yes & -6 \\
\hline Yersinia enterocolityca & 4,2 & 0,96 & Yes & -2 \\
\hline Pseudomonas aeruginosa & 5,5 & 0,97 & No & $<0$ \\
\hline Bacillus cereus & 4,4 & 0,91 & Yes & $<4$ \\
\hline Vibrio parahaemolyticus & 4,8 & 0,94 & Yes & 5 \\
\hline \multicolumn{5}{|c|}{ Causative microorganisms of microbial spoilage } \\
\hline Lactic acid bacteria & 3,8 & 0,94 & Yes & 4 \\
\hline Micrococcus & 5,5 & 0,97 & No & 4 \\
\hline Mold fungi & $<2$ & 0,60 & No & $<0$ \\
\hline Yeast & $1-5$ & 0,80 & Yes & -5 \\
\hline
\end{tabular}


likely that different values will be appropriate to it. Therefore, it is necessary to apply the safety (reserve) coefficient for experimentally determined sell-by date. The safety coefficient can vary between $15 \%$ to $100 \%$ for various food categories $[4,5]$. It concerns both the study duration and the storage temperature of these samples. The further study at a temperature which is $50 \%$ higher than regulated one by technical documentation is required for products with short sell-by date which have been treated at a temperature $<800 \mathrm{C}$ or have been in contact with staff's hands [5].

The frequency of testing during the study depends on the microbiological stability of the product - perishable foodstuffs should be tested more often. The minimum essential number of samples for testing is determined [7], but, in any events, this number is not supposed to be less than three units from different production lots [4]. Evaluating results of testing, it should be taken into account that "absence of microorganisms" does not evidence the microbial limits of the product, although, there was a low-detection probability of small quantity of pathogens, irregularity in their distribution and variability of microorganisms' reproduction within the product. It is recommended to apply a rule of decision-making which is based not on averageweighted data about microorganisms' content, but on the upper bound of the confidence interval with the probability level between $90 \%$ to $95 \%$.

The artificial inoculation of the product (challenge test) is necessary in the case of novel products on which the available information is not sufficient. It requires the preliminary determination of certain type (and sometimes even certain strain) of microorganism and quantitative parameters of inoculation. In the event of causative microorganisms of microbial spoilage (lactobacillus and yeast) it must be strains (not less than 5 units) which have been seeded from similar type of products. The experiments associated with artificial inoculation by pathogenic microorganisms must be conducted in specialized laboratories outside of food establishments. Findings, relating to product's ability to maintain/not maintain the growth of such pathogens as L.monocytogenes, provide the basis for further monitoring in the process of production and distribution [8]. The number of microorganisms used to inoculate the product should be significantly higher than normal level of microbial cont- amination. Considering the possibility of death of some inoculated in the product microorganisms during the initial period of their adaptation to new conditions of existence (die-off), the initial quantity of inoculum must be $>104$ CFU/g (colonyforming units per gram). If the initial inoculum is not sufficient to compensate adaptative losses, it can lead to improper conclusion about microbiological stability of the product. Adaptative period of microorganisms (the lag phase analogue of germ culture life cycle) depends on the food composition including food additives presence and storage conditions.

The sell-by date duration of many products has stimulated the implementation of shortcut methods which also intend studies conducting within the conditions of elevated temperature, humidity, illumination intensity and other possible external factors of influence (aggravation). Findings are used to evaluate the sell-by date under normal conditions [3]. Despite the possibility of significant reduction of study time frame, all methods that apply aggravation have meaningful constrains by virtue of possible influences of elevated temperature on the water activity, denaturation of proteins, gases solubility, crystallization of amorphus carbohydrates, fats melting, course of chemical reactions. In connection with this, the veracity of results achieved by these methods should be confirmed by means of validation.

Mathematical model method ("prognostic microbiology") makes use of known data referring to microbial growth patterns in different external conditions. It is mainly used empirical models which can be probabilistic or kinetic $[8,9]$. Probabilistic models evaluate the probability of microorganisms' reproduction in marginal existence conditions. Despite widespread and continual improvement, mathematical modeling does not exclude the necessity of microbiological confirmation, but makes it possible to substantially optimize corresponding studies [10].

It is important to determine expedient duration of product's testing for further microbiological monitoring. (time to detect - TTD), that is time required for reproduction of targeted microorganisms to minimal boundary of determination by conventional methods. For instance, the initial point of TTD for L.monocytogenes is concentration of $1 \mathrm{CFU} / \mathrm{g}$ (colony-forming units per gram), but the endpoint is $100 \mathrm{CFU} / \mathrm{g}$ (colony-forming units per gram) (the most acceptable level of safety in European Union and Canada for readyto-eat products) $[1,11]$. 
Conclusion. Thus, in the process of microbiological substantiation of the sell-by date of food products it should be taken into account the presence of leading pathogen and causative microorganisms of microbial spoilage, the initial contamination level, the lag phase duration of germ culture development, variations between strains, the kinetics of microorganisms accumulation within the product in real and aggravated storage conditions, the indetermination connected with biological nature of microorganisms and their inhomogeneous allocation within the product, the limitation for shortcut research methods (if applicable). The decision rule should be based on the consumer's risk concept - as a result of testing of upper boundary of confidence interval instead of arithmetical mean.

\section{REFERENCES}

1. National Advisory Committee on Microbiological Criteria for Foods: Considerations for establishing safety-based consume-by date labels for refrigerated ready-to-eat foods // J.Food Prot. - 2005. V.68. - P.1761-1775.

2. Shelf life of foods - Guidelines for its determination and prediction. //Institute of food Science and Technology. - 1993. - London.

3. Kilcast D., Subramaniam P. The stability and shelf-life of food./D.Kilcast., P. Subramaniam.//.Kilcast D., Subramaniam P. eds. - CRC Press, Boca Raton. - 2000. - P.1-19.

4. Food Safe Authority of Ireland./Validation of Product Shelf life (Revision 4) FSAI, Dublin. - 2019. 43 P. [Elektronnyi resurs] - Rezhym dostupu: www.fsai.ie/food_business/micro_criteria/ legal_criteria/shelflife.html.

5. Sanitarno-epidemiologicheskaya otsenka obosnovaniya srokov godnosti pischevykh produktov. MUK 4.2.1847-04. - MZ RF. - $2004-31 \mathrm{c}$.

6. Latiful Bari. Determinatiom of Microbial Shelf life of Food-A review./Bari Latiful// Jpn.J. Food Microbiol. - 2009. - V.26(3). - P. 139--149.

7. The International Commission on Microbiological Specifications for Foods (Last Accessed July 28th 2014) Software tool to determine the performance of statistical sampling plans that are used to assess the microbiological quality of batches of food. [Elektronnyi resurs]. - Rezhym dostupu: www.icmsf.org/main/software_downloads.html/.

8. Commission Regulation (EC) № 2073/2005 of 15 november 2005. Microbiological Criteria for foodstaffs.// Official J. of the European Union. - 2005. - L.338/1 - L.338/26.

9. ComBase Predictor assested on-line. 3 november 2009. [Elektronnyi resurs]. - Rezhym dostupu: wwwdev.

Ifrn.bbsrc.ac.uk/CombasePMP/GP/Login.aspx?ReturnUrl=\%2fCombasePM\%2fGP\%2fDefaut.aspx.

10. Blackburn $C$ de W. Modelling shelf life. The stability and shelf life of food./C. DeW.

Blackburn // Kilcast D., Subramaniam P. eds. - CRC Press, Boca Raton, FL. - 2000. - P.55-75.

11. Pal A. Safety-based shelf life model for frankfurters based on time to detect Listeria monocytogenes with initial inoculum below detection limit/ A. Pal., T.Labuza, F. Diez-Gonsalenz // J. Food. Prot. - 2009. - V.72. - P.1878-1884.

\section{ОБҐРУНТУВАННЯ ТЕРМІНУ РЕАЛІЗАЦІЇ ХАРЧОВОЇ ПРОДУКЦІЇ}

С.М. КУзьминський, Т.В. АдамчУк, О.М. Голінько, Н.П. Левицька

ДП “Науковий центр превентивної токсикології, харчової та хімічної безпеки імені академіка Л.І. Медведя Міністерства охорони здоров'я України", м. Київ, Україна

PЕЗЮМЕ. Мета роботи. Огляд сучасних методичних підходів до експериментального обгрунтування термінів реалізації харчових продуктів.

Матеріали та методи. Аналіз даних наукової літератури та нормативних документів щодо методів обгрунтування термінів реалізації харчових продуктів.

Результати. Термін реалізації - це період від моменту виготовлення продукту, протягом якого він зберігає свою безпечність та якість (включно з поживною цінністю) в обгрунтовано-прогнозованих умовах зберігання, дистрибуції та споживання. Термін реалізації необхідно переглядати в разі впровадження нових продуктів (рецептур), а також за потреби його збільшення. Обговорюються основні аспекти мікробіологічного обгрунтування термінів реалізації харчових продуктів. Першим етапом роботи $\epsilon$ ідентифікація мікробної небезпеки для конкретного продукту. Наступним етапом $є$ встановлення кінетичних параметрів накопичування визначеного мікроорганізму до максимально допустимого рівня в регламентованих та агравованих умовах зберігання продукту. 
Висновки. При мікробіологічному обґрунтуванні термінів реалізації харчових продуктів слід враховувати наявність провідного патогена та збудників мікробного псування, рівень ініціальної контамінації, тривалість лаг-фази розвитку мікробної культури, міжштамові варіації, кінетику накопичення мікроорганізмів у продукті за реальних і агравованих умов зберігання, невизначеність, пов'язану із біологічною природою мікроорганізмів та неоднорідністю їхнього розподілу в продукті, обмеження для прискорених методів дослідження (в разі їхнього застосування). Правило прийняття рішень має ґрунтуватись на концепції споживчого ризику.

Ключові слова: харчові продукти, термін реалізації, обґрунтування, мікробіологічні показники.

\section{ОБОСНОВАНИЕ СРОКА РЕАЛИЗАЦИИ ПИЩЕВОЙ ПРОДУКЦИИ}

С.М. Кузминский, Т.В. Адамчук, О.Н. Голинько, Н.П. Левицкая

ГП «Научный центр превентивной токсикологии, пищевой и химической безопасности имени академика Л.И. Медведя Министерства здравоохранения Украины», г. Киев, Украина

РЕЗЮМЕ. Цель работы. Обзор современных методических подходов к экспериментальному обоснованию сроков реализации пищевых продуктов.

Материалы и методы. Анализ данных научной литературы и нормативных документов, касающихся обоснования сроков реализации пищевых продуктов.

Результаты. Срок реализации - это период от момента приготовления пищевого продукта, в течение которого этот продукт сохраняет свою безопасность и качество (включая питательную ценность) в обоснованно-прогнозируемых условиях хранения, дистрибуции и потребления. Обоснование срока реализации необходимо при внедрении новых продуктов (рецептур), а также при необходимости его продления. Обсуждаются основные аспекты микробиологического обоснования сроков реализации пищевых продуктов, а именно идентификация ведущего патогена и возбудителей микробной порчи, уровень инициальной контаминации, длительность лаг-фазы, межштаммовые вариации, кинетика накопления микроорганизмов в продукте в реальных и агравированных условиях хранения, неопределенность, связанная с биологической природой микроорганизмов и неоднородностью их распределения в продукте, ограничения ускоренных методов исследования (в случае их использования). Правило принятия решений должно основываться на концепции потребительского риска - принятие в качестве результата тестирования верхнего предела доверительного интервала вместо средней арифметической.

Выводы. Унификация методики экспериментального обоснования сроков реализации пищевых продуктов достаточно важна для Украины. При проведении исследований необходимо учитывать присутствие основного патогена и возбудителей микробной порчи, уровень инициальной контаминации, длительность лаг-фазы развития микробной культуры, межштаммовые вариации, кинетику накопления микроорганизмов в продукте в реальных и агравированных условиях хранения, неопределенность, связанную с биологической природой микроорганизмов и неоднородностью их распределения в продукте, ограничения для ускоренных методов исследования (в случае их использования). Принятие решений, как правило, должно основываться на концепции потребительского риска.

Ключевые слова: пищевые продукты, сроки реализации, обоснование, микробиологические показатели.

Received 12/05/2019 